\title{
Sex-Dependent Antipsychotic Capacity of $17 \beta$-Estradiol in the Latent Inhibition Model: A Typical Antipsychotic Drug in Both Sexes, Atypical Antipsychotic Drug in Males
}

\author{
Michal Arad*,' and Ina Weiner' \\ 'Department of Psychology, Tel-Aviv University, Tel-Aviv, Israel
}

\begin{abstract}
The estrogen hypothesis of schizophrenia suggests that estrogen is a natural neuroprotector in women and that exogenous estrogen may have antipsychotic potential, but results of clinical studies have been inconsistent. We have recently shown using the latent inhibition (LI) model of schizophrenia that $17 \beta$-estradiol exerts antipsychotic activity in ovariectomized (OVX) rats. The present study sought to extend the characterization of the antipsychotic action of $17 \beta$-estradiol $(10,50$ and $150 \mu \mathrm{g} / \mathrm{kg}$ ) by testing its capacity to reverse amphetamine- and MK-80 I-induced LI aberrations in gonadally intact female and male rats. No-drug controls of both sexes showed LI, ie, reduced efficacy of a previously non-reinforced stimulus to gain behavioral control when paired with reinforcement, if conditioned with two but not five tone-shock pairings. In both sexes, amphetamine ( I mg/kg) and MK-80I $(50 \mu \mathrm{g} / \mathrm{kg}$ ) produced disruption (under weak conditioning) and persistence (under strong conditioning) of $\mathrm{LI}$, modeling positive and negative/cognitive symptoms, respectively. $17 \beta$ estradiol at 50 and $150 \mu \mathrm{g} / \mathrm{kg}$ potentiated $\mathrm{LI}$ under strong conditioning and reversed amphetamine-induced LI disruption in both males and females, mimicking the action of typical and atypical antipsychotic drugs (APDs) in the LI model. I7 $\beta$-estradiol also reversed MKinduced persistent $\mathrm{LI}$, an effect mimicking atypical APDs and NMDA receptor enhancers, but this effect was observed in males and OVX females but not in intact females. These findings indicate that in the LI model, I $7 \beta$-estradiol exerts a clear-cut antipsychotic activity in both sexes and, remarkably, is more efficacious in males and OVX females where it also exerts activity considered predictive of anti-negative/cognitive symptoms.
\end{abstract}

Neuropsychopharmacology (2010) 35, 2179-2192; doi: I0.1038/npp.2010.89; published online 7 July 2010

Keywords: amphetamine; antipsychotic drugs; MK-80I; estrogen; latent inhibition; schizophrenia

\section{INTRODUCTION}

Epidemiological and life cycle studies have indicated that women with schizophrenia have a more favorable illness course than men during reproductive years, characterized by later onset of symptoms, lower symptom severity and better response to antipsychotic drugs (APDs); however, the menopausal period is associated with increased symptom severity and reduced sensitivity to treatment (Hafner, 2003; Hafner et al, 1989; Kulkarni, 2009; Kulkarni et al, 1996, 2008b; Riecher-Rossler and de Geyter, 2007; Seeman and Lang, 1990). This has led to the suggestion that exogenous estrogen may have therapeutic potential in women with schizophrenia, but results of clinical studies have been inconclusive (Akhondzadeh et al, 2003; Korhonen et al, 1995; Kulkarni et al, 2008a; Kulkarni et al, 1996; Kulkarni

*Correspondence: M Arad, Department of Psychiatry, University of Maryland School of Medicine, Room 916 MSTF, 685 West Baltimore Street, Baltimore, MD 2120I, USA, Tel: + 410706 6799, Fax: + 410 706 4002, E-mail: marad@psych.umaryland.edu

Received I0 March 20 I0; revised 25 May 20 I0; accepted 27 May 2010 et al, 2008b; Kulkarni et al, 2001; Mortimer, 2007; RiecherRossler, 2002; Riecher-Rossler and de Geyter, 2007; RiecherRossler and Hafner, 1993; Riecher-Rossler et al, 1994). Interestingly, estradiol improved psychotic symptoms also in schizophrenic men (Kulkarni, 2009).

Support for the antipsychotic action of estrogen can be derived from animal studies showing that $17 \beta$-estradiol blocks/reduces the behavioral response to the pro-psychotic dopaminergic drugs, amphetamine and cocaine, (Becker and Beer, 1986; Becker and Rudick, 1999; Bedard et al, 1983; Bedard et al, 1978; Gordon and Diamond, 1981; Hafner et al, 1991; Naik et al, 1978; Segarra et al, 2009) and potentiates APD-induced catalepsy (Bedard et al, 1982; Chiodo et al, 1979; De Ryck et al, 1982; Di Paolo et al, 1979; Nicoletti et al, 1983; Palermo-Neto and Dorce, 1990). 17 $\beta$ estradiol has been also shown to improve cognitive performance in humans and rodents of both sexes (Barnes et al, 2006; Daniel and Bohacek, 2010; Frick, 2009; Gogos et al, 2006; Kitamura et al, 2009; Packard et al, 1996; Sherwin et al, 2009; Soderstrom et al, 2009). Such action would be beneficial in schizophrenia which is characterized by profound cognitive deficits (Barch and Carter, 2008). 
To date, the study of the antipsychotic capacity of estrogen in formal animal models of schizophrenia has been limited (Chavez et al, 2009; Gogos et al, 2010; Hafner et al, 1991; Sutcliffe et al, 2008; Van den Buuse and Eikelis, 2001).

We have recently provided evidence for antipsychotic properties of estrogen using the latent inhibition (LI) model of schizophrenia (Arad and Weiner 2008, 2009, 2010). LI is one of the best-documented cross-species manifestations of attentional selectivity in associative learning (Lubow, 1989; Mackintosh, 1975), whereby repeated non-reinforced preexposure to the to-be-conditioned stimulus interferes with its subsequent efficacy to generate conditioned response. Amphetamine-induced disruption of LI is considered to model the inability to ignore irrelevant stimuli associated with positive symptoms of schizophrenia (Weiner, 2003). Conversely, rodents treated with NMDA receptor antagonists such as MK-801 or PCP that produce and exacerbate negative symptoms and cognitive deficits (Javitt and Zukin, 1991; Krystal et al, 2003), persist in expressing LI under conditions that prevent/reduce LI expression in untreated rats (Gaisler-Salomon et al, 2008; Gaisler-Salomon and Weiner, 2003; Lipina et al, 2005; Palsson et al, 2005). Thus, persistent LI induced by MK- 801 has been suggested to model attentional perseveration associated with negative/ cognitive symptoms of schizophrenia (Gaisler-Salomon et al, 2008; Weiner and Arad 2009). Both typical and atypical APDs restore LI in amphetamine-treated rats, and this is paralleled by their capacity to restore LI in naive animals under conditions that do not yield robust LI in no-drug controls (Weiner and Arad 2009). MK-801-induced persistent LI is reversed by atypical but not typical APDs, as well as by glycinergic NMDA enhancers, consistent with the differential efficacy of these treatments in improving negative/cognitive symptoms (Harvey et al, 2005; Heresco-Levy et al, 2005).

In support of the antipsychotic action of $17 \beta$-estradiol, we (Arad and Weiner 2008, 2009, 2010) showed that (a) disruption and restoration of LI are associated with low and high levels of endogenous estrogen; (b) behaviorally inactive dose of $17 \beta$-estradiol restores the capacity of ineffective APD doses to block amphetamine-induced LI disruption; and (c) $17 \beta$-estradiol given on its own reverses amphetamine-induced LI disruption in ovariectomized (OVX) as well as in sham-operated female rats. Our aim here was to extend the characterization of the antipsychotic action of $17 \beta$-estradiol by testing its capacity to reverse amphetamine-induced LI disruption and MK-801-induced LI persistence in gonadally intact female and male rats. In addition, we tested whether $17 \beta$-estradiol on its own potentiates LI.

\section{MATERIALS AND METHODS}

\section{Animals}

Female and male Wistar rats, 3-month old, bred in our laboratory were housed by sex, four per cage under reversed cycle lighting (lights on: $07: 00-19: 00 \mathrm{~h}$ ) with ad lib access to food and water except for the duration of the LI experiments. All experimental protocols conformed to the guidelines of the Institutional Animal Care and Use Committee of Tel-Aviv University, Israel, and to the guidelines of the NIH (animal welfare assurance number A5010-01, expires on 30 September 2011). All efforts were made to minimize the number of animals used and their suffering.

\section{Ovariectomy (OVX)}

Female rats were bilaterally ovariectomized under isoflurane (Nichols Piramal, UK) anesthesia. After shaving the abdominal area, a midline incision was made through the skin and muscle layer. Fallopian tubes were ligated by a nylon thread, after which the ovaries were carefully removed. Sutures of muscle layer and skin were removed 10 days later. Rats were allowed additional 3 weeks of recovery after removal of the sutures before the beginning of water restriction (see below). Within the 3-week recovery period, about a week after removal of sutures, vaginal smears were collected daily in the morning for 8 days in sham and OVX rats, to confirm presence or discontinuation estrous cycle, respectively. Phases of the estrous cycle were determined by the morphology of cells in the vaginal smear under a light microscope (Marcondes et al, 2002). Sham-operated female and male controls (in experiment 4) underwent an identical surgical procedure without ovaries' removal. Sham females with two regular 4-day cycles in succession and OVX rats without estrous cycle were used for behavioral testing.

\section{Apparatus and Procedure}

LI was measured in a thirst-motivated conditioned emotional response procedure in Campden Instruments rodent test chambers with a retractable bottle, each enclosed in a ventilated sound-attenuating chest. When the bottle was not present, the hole was covered with a metal lid. The preexposed (PE) to-be-conditioned stimulus was a $10 \mathrm{~s}, 80 \mathrm{~dB}$, $2.8 \mathrm{kHz}$ tone produced by a Sonalert module. Shock was supplied through the floor by a Campden Instruments shock generator and shock scrambler set at $0.5 \mathrm{~mA}$ intensity and $1 \mathrm{~s}$ duration. Licks were detected by a Campden Instruments drinkometer. Equipment programming and data recording were controlled by the computer.

At 10 days before the beginning of the LI procedure, rats were put on a $23 \mathrm{~h}$ water restriction schedule and handled for about $2 \mathrm{~min}$ daily for 5 days. On the next 5 days, rats were trained to drink in the experimental chamber for $15-20 \mathrm{~min} /$ day. Water in the test apparatus was given in addition to the daily ration of $1 \mathrm{~h}$ given in the home cages. The LI procedure was conducted on days 11-14 and consisted of four stages given $24 \mathrm{~h}$ apart:

Pre-exposure. With the bottle removed, the PE rats received 40 tone presentations with an inter-stimulus interval of $40 \mathrm{~s}$. The non-pre-exposed (NPE) rats were confined to the chamber for an identical period of time without receiving the tone.

Conditioning. With the bottle removed, rats received two (weak conditioning) or five (strong conditioning) tone-shock pairings given $5 \mathrm{~min}$ apart. Shock immediately followed tone termination. Weak conditioning produces LI in non-treated controls and thus allows the demonstration of treatmentinduced LI disruption. This level of conditioning was therefore used with amphetamine (experiments 5 and 6). 
Conversely, strong conditioning prevents LI in non-treated controls and thus allows the demonstration of treatmentinduced abnormally persistent LI. This level of conditioning was used with MK-801 (experiments 7, 8, and 9). Both levels were used with $17 \beta$-estradiol administration on its own (experiments $1,2,3$, and 4 ) to determine if $17 \beta$-estradiol disrupts and/or potentiates LI.

Rebaseline. Rats were given a 15 min drinking session as in initial training.

Test. Each rat was placed in the chamber and allowed to drink from the bottle. When the rat completed 75 licks the tone was presented for $5 \mathrm{~min}$. The following times were recorded: Time to first lick, time to complete 1-50 licks, time to complete 51-75 licks (before the tone onset), and time to complete 76-100 licks (after the tone onset). Times to complete 76-100 licks were submitted to logarithmic transformation to allow parametric ANOVA. Longer log times indicate stronger suppression of drinking. LI is defined as significantly shorter log times to complete 76-100 licks of the PE compared with NPE rats.

\section{Drug and Hormone Administration}

Amphetamine, MK-801, and $17 \beta$-estradiol were administered in a volume of $1 \mathrm{ml} / \mathrm{kg}$. Amphetamine (Sigma, Switzerland) was dissolved in saline and administered i.p. at a dose of $1 \mathrm{mg} / \mathrm{kg}$. MK-801 (dizocilpine; Merck Research Laboratories, USA) was dissolved in saline and administered i.p. at a dose of $50 \mu \mathrm{g} / \mathrm{kg}$. These doses are routinely used in our LI studies (Arad and Weiner 2010; Barak et al, 2009; Black et al, 2008). 17 $\beta$-estradiol (Sigma, Israel) was dissolved in corn oil and administered s.c. at doses of 10, 50, and $150 \mu \mathrm{g} / \mathrm{kg}$. These doses were used in our previous studies; they mimic low hormonal levels in female rats as seen during metestrus-diestrus, high levels as seen during proestrus-estrus, and very high levels as seen during the last trimester of pregnancy (Arad and Weiner, 2009, 2010; Galea et al, 2001; Gibbs et al, 1998; Nofrey et al, 2008; Van den Buuse and Eikelis, 2001; Walf and Frye, 2009). All compounds were administered before pre-exposure and conditioning sessions at $30 \mathrm{~min}$ interval for amphetamine and MK-801, and $120 \mathrm{~min}$ for $17 \beta$-estradiol. No-drug controls received the corresponding vehicles. In all experiments, rebaseline and test sessions were conducted in a drug-free state.

\section{Experimental Design}

Experiments 1 and 2 . Tested the effects of $17 \beta$-estradiol on LI under weak conditioning (forty pre-exposures and two conditioning trials) in gonadally intact female and male rats. The experiments included 40 females (exp 1; $\mathrm{n} /$ group $=5)$ and 40 males (exp 2; n/group = 5) divided into eight experimental groups in a $2 \times 4$ design with main factors of pre-exposure $(0,40)$ and hormonal treatment $(0,10,50$, and $150 \mu \mathrm{g} / \mathrm{kg} 17 \beta$-estradiol).

Experiments 3 and 4 . Tested the effects of $17 \beta$-estradiol on LI under strong conditioning (forty pre-exposures and five conditioning trials) in gonadally intact female and male rats. The experiments included 49 females (exp 3; $\mathrm{n} /$ group $=6-7$ ) and 62 males (exp 4; n/group =7-8) divided into eight experimental groups in a $2 \times 4$ design with main factors of pre-exposure $(0,40)$ and hormonal treatment $(0,10,50$, and $150 \mu \mathrm{g} / \mathrm{kg} 17 \beta$-estradiol $)$.

Experiments 5 and 6 . Tested the capacity of $17 \beta$-estradiol to reverse amphetamine-induced LI disruption (under weak conditioning) in gonadally intact female and male rats. The experiments included 92 females (exp 5; n/group $=7-8)$ and 94 males ( $\exp 6 ; \mathrm{n}$ /group $=7-8$ ) divided into twelve experimental groups in a $2 \times 2 \times 3$ design with main factors of pre-exposure $(0,40)$, pro-psychotic treatment $(0$ and $1 \mathrm{mg} / \mathrm{kg}$ amphetamine), and hormonal treatment $(0,50$, and $150 \mu \mathrm{g} / \mathrm{kg} 17 \beta$-estradiol).

Experiments 7, 8, and 9. Tested the capacity of $17 \beta$ estradiol to reverse MK-801-induced LI persistence (under strong conditioning) in gonadally intact female and male rats as well as in OVX female rats. The experiments included 73 intact females (exp 7; n/group =6-7), 85 intact males (exp 8; n/group $=7-8$ ), and 73 OVX females (exp 9; $\mathrm{n}$ /group $=6-7$ ) divided into twelve experimental groups in a $2 \times 2 \times 3$ design with main factors of pre-exposure $(0,40)$, pro-schizophrenia treatment ( 0 and $50 \mu \mathrm{g} / \mathrm{kg} \mathrm{MK}-801)$, and hormonal treatment $(0,50$, and $150 \mu \mathrm{g} / \mathrm{kg} 17 \beta$-estradiol).

\section{Statistical Analysis}

Time to complete 51-75 licks (before tone onset) and mean log times to complete 76-100 licks (after tone onset) were analyzed using two-way ANOVAs with main factors of pre-exposure and hormonal treatment (experiments 1, 2, 3, and 4) and three-way ANOVAs with main factors of pre-exposure, treatment, and hormonal treatment (experiments 5, 6, 7, 8, and 9). In cases of significant interactions involving the factor of pre-exposure, LSD posthoc comparisons were used to assess the difference between the PE and NPE groups within each treatment condition.

It is important to mention that in all experiments, females and males were run in different systems to avoid potential interference. Thus, we could not analyze their data in the same ANOVA. However, given that we had four main aims in this study, we introduced the results as well as the figures under each aim as different parts of the same experiment to allow a visual comparison between the females' and males' data.

\section{RESULTS}

There were no differences between the experimental groups in the time required to complete 51-75 licks (A period; all $p$ 's $>0.05$ ) in any of the experiments (overall mean A periods were $6.65,7.54,10.25,9.57,7.13,6.92,7.02,6.31$, and 9.44 for experiments $1,2,3,4,5,6,7,8$, and 9 , respectively).

\section{Experiments 1 and 2: Effects of $17 \beta$-Estradiol on LI Under Weak Conditioning (40 Pre-Exposures and Two Conditioning Trials) in Female and Male Rats}

The two parts of Figure 1, a (exp 1) and b (exp 2), present the mean log times to complete 76-100 licks (after tone 
onset) of the PE and NPE female (Figure 1a) and male (Figure $1 \mathrm{~b}$ ) rats treated with oil, 10,50 , or $150 \mu \mathrm{g} / \mathrm{kg}$ $17 \beta$-estradiol. As can be seen in both parts of Figure 1, oil-treated female and male rats showed LI, whereas rats treated with $10 \mu \mathrm{g} / \mathrm{kg}$ of $17 \beta$-estradiol did not show LI. The higher doses of $17 \beta$-estradiol (50 and $150 \mu \mathrm{g} / \mathrm{kg}$ ) spared LI. ANOVAs yielded significant main effects of pre-exposure (females: $\mathrm{F}_{(1,32)}=55.9, p<0.0001$; males: $\mathrm{F}_{(1,32)}=45.4$, $p<0.0001)$ and hormonal treatment (females: $\mathrm{F}_{(3,32)}=3.0$, $p<0.05$; males: $\left.\mathrm{F}_{(3,32)}=3.5, p<0.05\right)$, as well as a significant pre-exposure $\times$ hormonal treatment interaction (females: $\mathrm{F}_{(3,32)}=8.5, \quad p<0.0005$; males: $\left.\mathrm{F}_{(3,32)}=8.6, p<0.0005\right)$. Post-hoc comparisons for each of the analyses confirmed the presence of LI in female and male rats given oil, 50 , or $150 \mu \mathrm{g} / \mathrm{kg} 17 \beta$-estradiol ( $p$ 's $<0.01$ ), but not after $10 \mu \mathrm{g} / \mathrm{kg}$ $17 \beta$-estradiol.

Experiments 3 and 4: Effects of $17 \beta$-Estradiol on LI under strong Conditioning (40 Pre-Exposures and five Conditioning Trials) in Female and Male Rats

The two parts of Figure 2, a (exp 3) and b (exp 4), present the mean log times to complete 76-100 licks (after tone onset) of the PE and NPE female (Figure 2a) and male (Figure 2b) rats treated with oil, 10,50 , and $150 \mu \mathrm{g} / \mathrm{kg}$ $17 \beta$-estradiol. As can be seen, oil-treated female and male rats did not show LI as expected under strong conditioning. $10 \mu \mathrm{g} / \mathrm{kg}$ of $17 \beta$-estradiol had no effect on LI, whereas female and male rats treated with 50 and $150 \mu \mathrm{g} / \mathrm{kg}$ of $17 \beta$-estradiol persisted in showing LI. ANOVAs yielded a significant main effect of pre-exposure (females: $\mathrm{F}_{(1,41)}=8.1, p<0.01$; males: $\left.\mathrm{F}_{(1,54)}=18.7, p<0.0001\right)$, as well as a significant pre-exposure $\times$ hormonal treatment interaction (females: $\mathrm{F}_{(3,41)}=5.7, \quad p<0.005$; males: $\left.\mathrm{F}_{(3,54)}=4.2, \quad p<0.01\right)$. Post-hoc comparisons for each of the analyses confirmed the presence of LI in female and male rats given 50 or $150 \mu \mathrm{g} / \mathrm{kg} 17 \beta$-estradiol ( $p$ 's $<0.01$ ), but not in other conditions.

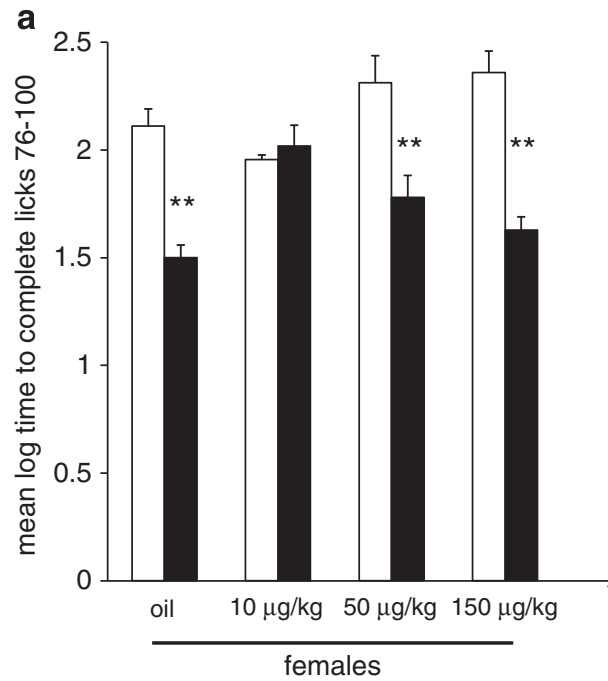

b

Experiments 7, 8, and 9: Effects of $17 \beta$-Estradiol on MK801-induced LI Persistence Under Strong Conditioning (40 Pre-Exposures and five Conditioning Trials) in Female, Male, and OVX Female Rats

The three parts of Figure 4, a (exp 7), b (exp 8), and c

(exp 9), present the mean log times to complete 76-100 licks

Experiments 5 and 6: Effects of $17 \beta$-Estradiol on Amphetamine-Induced LI Disruption Under Weak Conditioning (40 Pre-Exposures and two Conditioning Trials) in Female and Male Rats

The two parts of Figure 3, a (exp 5) and b (exp 6), present the mean log times to complete 76-100 licks (after tone onset) of the PE and NPE female (Figure 3a) and male (Figure $3 \mathrm{~b})$ rats treated with saline or amphetamine $(1 \mathrm{mg} /$ $\mathrm{kg}$ ), and pre-treated with oil, 50, or $150 \mu \mathrm{g} / \mathrm{kg} 17 \beta$-estradiol. As can be seen, under weak conditioning, vehicle-injected female and male rats exhibited LI, whereas amphetamineinjected female and male rats did not exhibit LI. Both doses of $17 \beta$-estradiol reversed amphetamine-induced LI disruption in females and males. On their own, both doses of $17 \beta$-estradiol spared LI in females and males. ANOVA for females yielded significant main effects of pre-exposure $\left(\mathrm{F}_{(1,80)}=98.9, \quad p<0.0001\right)$ and treatment $\left(\mathrm{F}_{(1,80)}=7.2\right.$, $p<0.01)$, as well as a significant pre-exposure $\times$ treatment $\times$ hormonal treatment interaction $\left(\mathrm{F}_{(2,80)}=3.2\right.$, $p<0.05)$. ANOVA for males yielded a significant main effect of pre-exposure $\left(\mathrm{F}_{(1,82)}=55.9, p<0.0001\right)$, as well as a significant pre-exposure $\times$ treatment $\times$ hormonal treatment interaction $\left(\mathrm{F}_{(2,82)}=7.4, p<0.005\right)$. Post-hoc comparisons for each of the analyses confirmed the presence of LI in saline-injected female and male rats pre-treated with 0 , 50 , or $150 \mu \mathrm{g} / \mathrm{kg} 17 \beta$-estradiol and in amphetamineinjected female and male rats pre-treated with 50 or $150 \mu \mathrm{g} / \mathrm{kg} 17 \beta$-estradiol $(p$ 's $<0.01)$, but not in the other conditions.
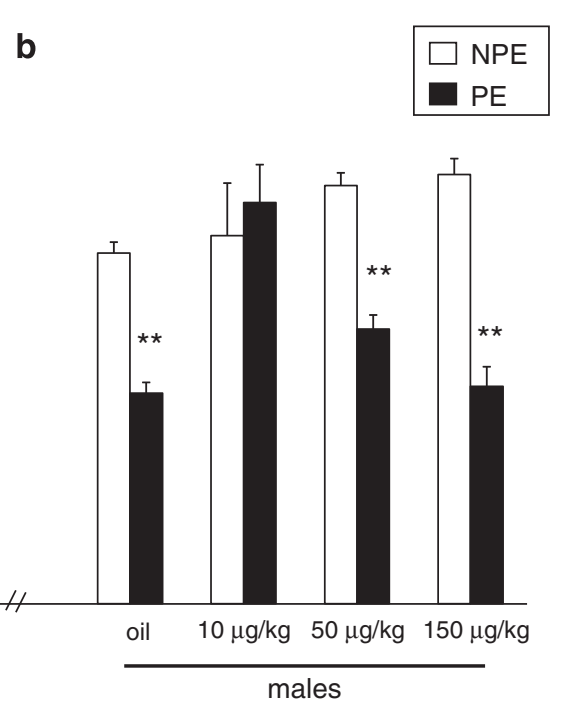

Figure I Effects of I $7 \beta$-estradiol on $\mathrm{LI}$ under weak conditioning (forty pre-exposures and two conditioning trials) in female and male rats. Mean ( \pm SEM) log time to complete 76-100 licks (after the tone onset) of the PE and the NPE female (a) and male (b) rats administered with 0, I0, 50, or I50 $\mu \mathrm{g} / \mathrm{kg}$ of $17 \beta$-estradiol (oil, 10, 50, or $150 \mu \mathrm{g} / \mathrm{kg}$, respectively). Asterisks indicate a significant difference between the PE and NPE groups, namely, presence of LI $(* * 0<0.0 I)$.

Neuropsychopharmacology 
a

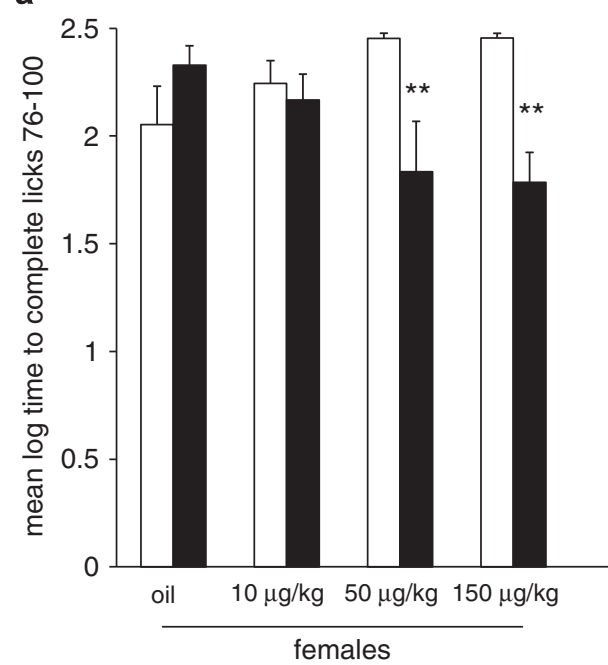

b

Figure 2 Effects of $17 \beta$-estradiol on $\mathrm{LI}$ under strong conditioning (forty pre-exposures and five conditioning trials) in female and male rats. Mean ( $\pm \mathrm{SEM}$ ) log times to complete 76- 100 licks (after the tone onset) of the PE and the NPE female (a) and male (b) rats administered with 0, I0, 50, or I50 $\mu \mathrm{g} / \mathrm{kg}$ of $17 \beta$-estradiol (oil, 10, 50, or $150 \mu \mathrm{g} / \mathrm{kg}$, respectively). Asterisks indicate a significant difference between the PE and NPE groups, namely, presence of LI $(* * 0.01)$.
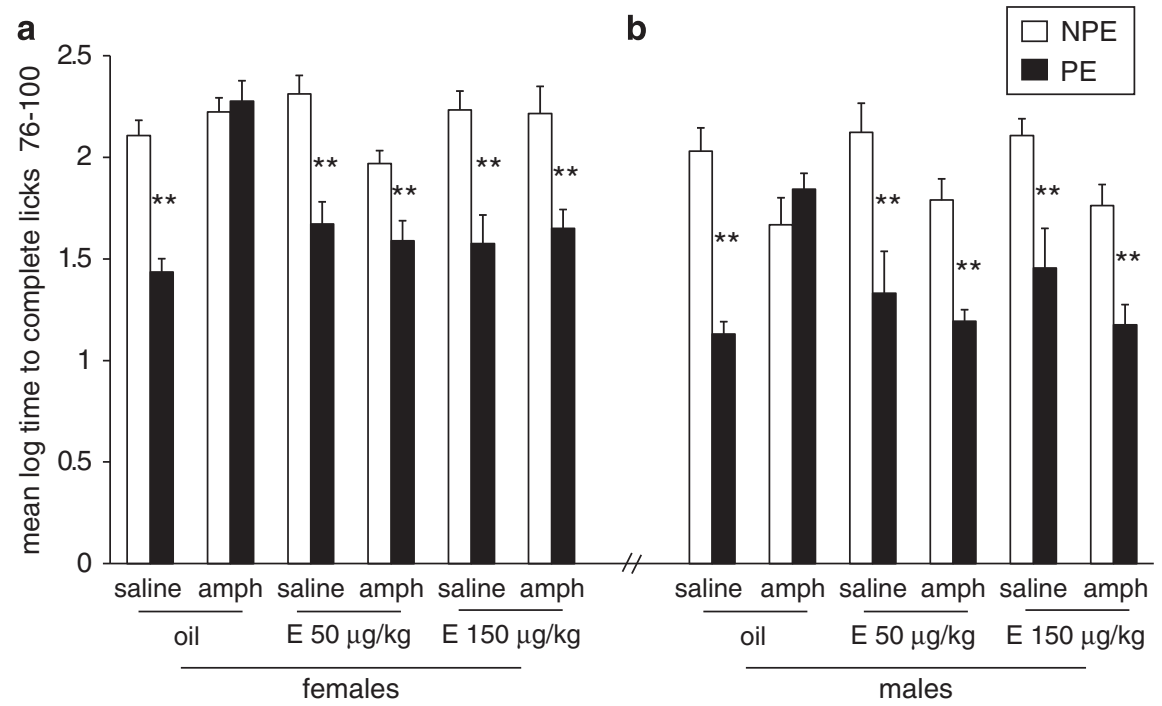

Figure 3 Effects of $17 \beta$-estradiol on amphetamine (amph)-induced LI disruption under weak conditioning (forty pre-exposures and two conditioning trials) in female and male rats. Mean ( \pm SEM) log times to complete 76-100 licks (after the tone onset) of the PE and the NPE saline- or amph-injected female (a) and male (b) rats, administered with 0,50 , or $150 \mu \mathrm{g} / \mathrm{kg}$ of $17 \beta$-estradiol (oil, E $50 \mu \mathrm{g} / \mathrm{kg}$, or E I $50 \mu \mathrm{g} / \mathrm{kg}$, respectively). Asterisks indicate a significant difference between the PE and NPE groups, namely, presence of $\mathrm{LI}(* * \mathrm{P}<0.0 \mathrm{I})$.

(after tone onset) of the PE and NPE female (Figure 4a), male (Figure 4b), and OVX female (Figure 4c) rats treated with saline or MK-801 $(50 \mu \mathrm{g} / \mathrm{kg})$, and pre-treated with oil, 50 , or $150 \mu \mathrm{g} / \mathrm{kg} 17 \beta$-estradiol. As expected with strong conditioning, LI was absent in vehicle-injected rats, whereas MK-801-injected rats persisted in showing LI. In MK-801treated female rats, both doses of $17 \beta$-estradiol were without any effect, whereas in males and OVX females, both doses reversed MK-801-induced LI persistence. On its own, $17 \beta$-estradiol led to LI in gonadally intact female and male rats, but not in OVX female rats. ANOVA for female rats yielded significant main effects of preexposure $\left(\mathrm{F}_{(1,61)}=58.0, p<0.0001\right)$, treatment $\left(\mathrm{F}_{(1,61)}=17.7\right.$, $p<0.0001)$, and hormonal treatment $\left(\mathrm{F}_{(2,61)}=5.6, p<0.01\right)$, as well as a significant pre-exposure $\times$ treatment $\times$ hormonal treatment interaction $\left(\mathrm{F}_{(2,61)}=3.4, p<0.05\right)$. ANOVA for male rats yielded a significant main effect of preexposure $\left(F_{(1,73)}=33.2, p<0.0001\right)$, as well as a significant pre-exposure $\times$ treatment $\times$ hormonal treatment interaction $\left(\mathrm{F}_{(2,73)}=11.6, p<0.0001\right)$. ANOVA for OVX female rats yielded significant main effects of pre-exposure $\left(\mathrm{F}_{(1,61)}=\right.$ $6.0, p<0.05)$ and treatment $\left(\mathrm{F}_{(1,61)}=27.7, p<0.0001\right)$, as well as a near significant pre-exposure $\times$ treatment $\times$ hormonal treatment interaction $\left(\mathrm{F}_{(2,61)}=2.97, p=0.059\right)$. Post-hoc comparisons for each of the analyses confirmed the presence of LI in saline-injected female and male rats given 50 or $150 \mu \mathrm{g} / \mathrm{kg} 17 \beta$-estradiol, in MK-801-injected female rats given 0,50 , or $150 \mu \mathrm{g} / \mathrm{kg} 17 \beta$-estradiol, and in $\mathrm{MK}-801$-injected rats 


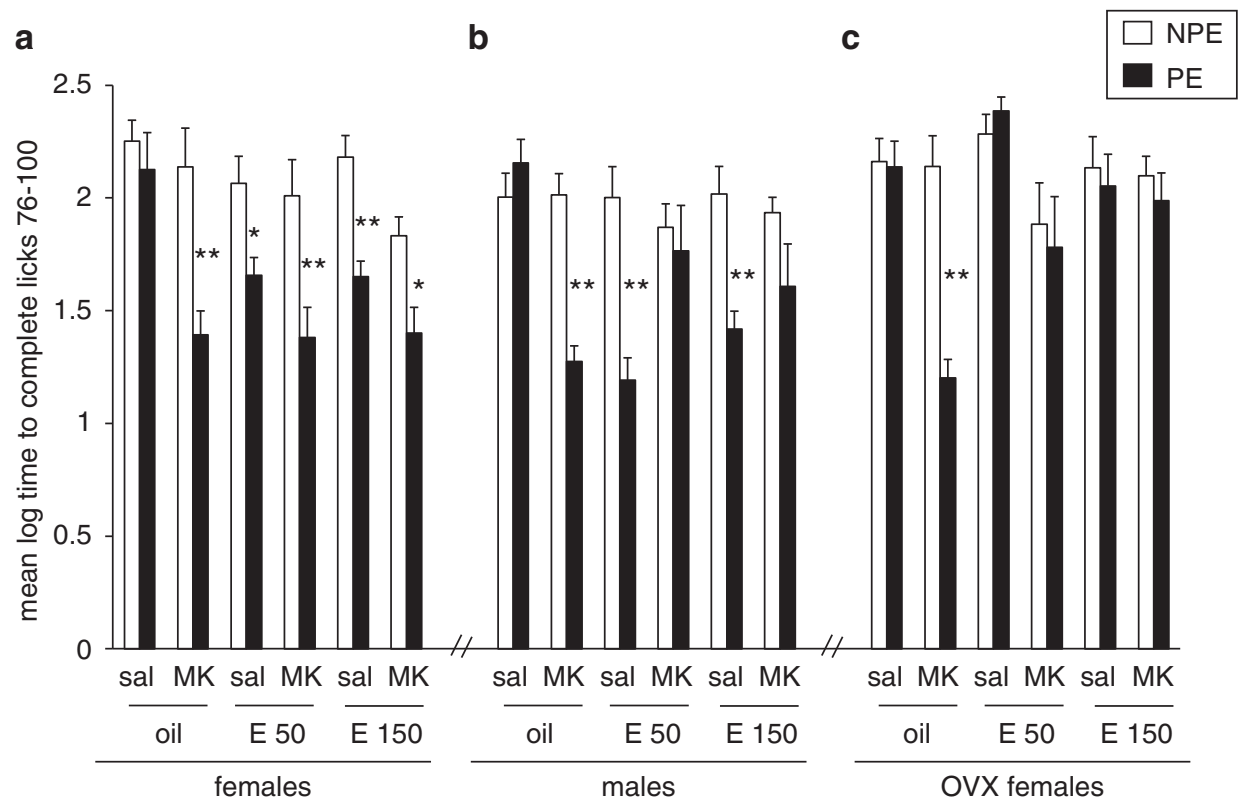

Figure 4 Effects of $17 \beta$-estradiol on MK-80I (MK)-induced LI persistence under strong conditioning (forty pre-exposures and five conditioning trials) in female, male, and OVX female rats. Mean ( \pm SEM) log times to complete 76-100 licks (after the tone onset) of the PE and the NPE saline (sal)- or MKinjected female (a), male (b), and OVX female (c) rats, administered with 0, 50, or $150 \mu \mathrm{g} / \mathrm{kg}$ of $17 \beta$-estradiol (oil, E 50, or E I50, respectively). Asterisks indicate a significant difference between the PE and NPE groups, namely, presence of $\mathrm{LI}(* p<0.05 ; * * 0<0.0 \mathrm{I})$.

given $0 \mu \mathrm{g} / \mathrm{kg} 17 \beta$-estradiol $(p$ 's $<0.05)$, but not in the other conditions.

\section{DISCUSSION}

The present study sought to assess whether estrogen exerts an antipsychotic action, as indexed by the LI model, in gonadally intact female and male rats. Using a nonpharmacological and two acute pharmacological LI models, we showed that: (1) under conditions yielding LI in nontreated controls, $10 \mu \mathrm{g} / \mathrm{kg} 17 \beta$-estradiol disrupted LI, whereas higher doses $(50$ and $150 \mu \mathrm{g} / \mathrm{kg}$ ) were without any effect in both sexes; (2) $17 \beta$-estradiol at higher doses restored LI under conditions preventing LI in non-treated controls, an effect considered predictive for activity against positive symptoms, in both sexes; (3) $17 \beta$-estradiol at higher doses reversed amphetamine-induced disruption of LI, an effect considered predictive for activity against positive symptoms, in both sexes; and (4) $17 \beta$-estradiol at higher doses reversed MK-801-induced persistent LI, an effect considered predictive for activity against negative/ cognitive symptoms, in gonadally intact male and OVX rats, but not in gonadally intact female rats (see Table 1). These findings indicate that in the LI model, $17 \beta$-estradiol exerts a clear-cut antipsychotic activity in both sexes and, remarkably, is more efficacious in males and OVX females, in which it also exerts activity considered predictive of antinegative symptoms/pro-cognitive action.

\section{Bimodal Effect of 17 $\beta$-Estradiol on LI}

$17 \beta$-estradiol, administered on its own, produced a dosedependent bimodal effect on LI in both female and male rats, with the low dose disrupting LI and the two higher doses restoring LI under conditions (strong conditioning) that disrupted LI in controls.

Potentiation or facilitation of LI under conditions of weak or absent LI in controls by APDs is a widely used index of antipsychotic activity. It is produced by a wide range of typical and atypical APDs and is also seen in normal humans (Barrett et al, 2004; Dunn et al, 1993; McCartan et al, 2001; Shadach et al, 1999; Weiner, 2003; Weiner and Arad 2009; Weiner and Feldon 1987; Williams et al, 1996; Williams et al, 1997). The fact that higher doses of $17 \beta$ estradiol produced a pattern typically found for APDs suggests that at these doses, $17 \beta$-estradiol may have antipsychotic properties.

The LI-facilitating effect of $17 \beta$-estradiol was restricted to high doses as the low dose of $10 \mu \mathrm{g} / \mathrm{kg}$ disrupted LI in both sexes. We have previously obtained this same bimodal effect of $17 \beta$-estradiol on LI in OVX rats (Arad and Weiner, 2010) and Nofrey et al (2008) have also reported LI-disrupting effect of $10 \mu \mathrm{g} / \mathrm{kg} 17 \beta$-estradiol in OVX rats. The fact that $17 \beta$-estradiol produces contrasting effects on LI at low and high doses implies that estradiol acts dose-dependently on different neural substrates. One likely substrate is the dopaminergic system. APD-induced LI potentiation is mediated by blockade of DA transmission within the nucleus accumbens (NAC) at the time of conditioning (Gray et al, 1995a; Gray et al, 1997; Joseph et al, 2000; Warburton et al, 1996; Weiner 2003). Consequently, our results imply that the higher doses of $17 \beta$-estradiol, which potentiated LI, reduced mesolimbic DA function. Conversely, low dose, which disrupted LI, may have acted by increasing DA release within the NAC as does the amphetamine (Warburton et al, 1996). Both reduction and increase of striatal dopaminergic function by $17 \beta$ estradiol have been reported for all indices of dopaminergic activity, including receptor levels/binding, membrane 
Table I Summary of Experimental Design and Results

\begin{tabular}{|c|c|c|c|c|c|c|c|}
\hline & \multirow[t]{2}{*}{ Tone-shock pairings } & \multirow[t]{2}{*}{ Sex } & \multirow[t]{2}{*}{ Pro-psychotic treatment } & \multicolumn{4}{|c|}{ Doss of I7ß-estradiol } \\
\hline & & & & Vehicle & $10 \mu \mathrm{g} / \mathrm{kg}$ & $50 \mu \mathrm{g} / \mathrm{kg}$ & $150 \mu \mathrm{g} / \mathrm{kg}$ \\
\hline Experiments 1 and 2 & & M & - & LI & No LI & LI & LI \\
\hline Experiments 3 and 4 & 5 & $\mathrm{~F}$ & - & No LI & No LI & LI & LI \\
\hline \multirow{3}{*}{ Experiments 5 and 6} & & & Amph & No LI & - & LI & LI \\
\hline & & M & Sal & LI & - & LI & LI \\
\hline & & & Amph & No LI & - & LI & LI \\
\hline \multirow[t]{3}{*}{ Experiments 7-9 } & 5 & $\mathrm{~F}$ & Sal & No LI & - & LI & LI \\
\hline & & & MK & LI & - & LI & LI \\
\hline & & & MK & $\mathrm{LI}$ & - & No LI & No LI \\
\hline
\end{tabular}

Abbreviations: Amph, amphetamine; F, female; LI, latent inhibition; M, male; MK, MK-80I; OVX, ovariectomy; Sal, saline; —, has not been administered.

dopamine transporter levels, and release, depending on dose and treatment paradigm (Arvin et al, 2000; Becker, 1999; Chavez et al, 2010; Di Paolo, 1994; Disshon et al, 1998; Dluzen and Horstink, 2003; McDermott, 1993; Morissette et al, 2008; Morissette and Di Paolo, 1993; Peris et al, 1991; Shieh and Yang, 2008; Thompson and Moss, 1994; Yu et al, 2009; Zhou et al, 2002). It has been suggested that antidopaminergic effects are primarily exerted by high doses of estrogen or chronic administration, whereas pro-dopaminergic actions are more associated with lower levels of estrogen (Barber et al, 1976; Becker, 1999; Bedard et al, 1977; Chavez et al, 2010; Cyr et al, 2002; Di Paolo, 1994; Di Paolo et al, 1981; Hruska and Silbergeld, 1980; McEwen and Alves, 1999; Riddoch et al, 1971; Yu et al, 2009). Although the specific mechanisms by which $17 \beta$-estradiol exerts its dose-dependent effects on LI observed here remain to be elucidated, if both effects are indeed DA-mediated, this would imply that low $17 \beta$-estradiol doses exert a propsychotic action.

An alternative mechanism for the dose-dependent effect of $17 \beta$-estradiol can be derived from our finding that a similar dose-dependent bimodal effect is produced by atypical APDs, such as risperidone, which disrupts LI at low doses and potentiates LI at higher doses (Weiner et al, 2003). The LI disruptive effect of atypical APDs is distinct from that of amphetamine because it occurs in the preexposure stage and is mediated by $5 \mathrm{HT}_{2 \mathrm{~A}}$ antagonism, whereas the disruptive effect of amphetamine occurs in the conditioning stage and is mediated by enhanced DA transmission. As estrogen modulates brain serotonergic activity and specifically the $5 \mathrm{HT}_{2 \mathrm{~A}}$ receptors (Fink et al, 1998; Sumner and Fink, 1997), this could be the mechanism underlying the LI disruptive action of low $17 \beta$-estradiol, and thus reflect an atypical antipsychotic action of this hormone. Clearly it is of interest to determine whether low estrogen is pro-psychotic or antipsychotic. Testing the effects of APDs on $17 \beta$-estradiol-induced LI disruption would be one straightforward way to answer this question; In addition, these alternatives can be teased out by assessing at which stage $17 \beta$-estradiol acts to disrupt LI.

\section{Reversal of Disrupted LI: Putative Efficacy for Positive Symptoms}

Amphetamine-induced LI disruption and its reversal by both typical and atypical APDs in the male rodent is a long standing model of positive symptoms (Weiner, 2003; Weiner and Arad, 2009). Although gender differences in response to amphetamine and other psychostimulants have been widely reported (for review see Fattore et al, 2008), such differences are not evident in the pro-psychotic action of amphetamine in the LI model (Arad and Weiner, 2010). Disruption of LI reflects a selective attention deficit, whereby animals lose the capacity to ignore the irrelevant stimulus, and is also observed in amphetamine-treated humans and high-schizotypal humans, (BraunsteinBercovitz et al, 2002; Gray et al, 1992b; Salgado et al, 2000; Swerdlow et al, 2003; Thornton et al, 1996) as well as in acutely psychotic schizophrenia patients (Baruch et al, 1988; Gray et al, 1992a; Gray et al, 1995b; Rascle et al, 2001; Swerdlow et al, 2005). A failure to inhibit attention to irrelevant stimuli is likely to give rise to aberrantly increased salience perception and distractibility that are associated with psychotic symptoms (Kapur et al, 2005; Weiner and Arad, 2009). $17 \beta$-estradiol at 50 and $150 \mu \mathrm{g} / \mathrm{kg}$ doses, which potentiated LI under conditions that disrupted LI in untreated gonadally intact rats (strong conditioning), also reversed amphetamine-induced LI disruption, as typically found with APDs. The present results replicate our recent finding (Arad and Weiner, 2010) that $17 \beta$-estradiol prevents amphetamine from disrupting LI in gonadally intact female rats and extends this action of $17 \beta$-estradiol to gonadally intact male rats. 
Reversal of amphetamine-induced LI disruption by APDs, like APD-induced potentiation of LI, is mediated by blockade of DA transmission within the NAC at the time of conditioning (Gray et al, 1995a; Gray et al, 1997; Joseph et al, 2000; Warburton et al, 1996; Weiner, 2003). Consequently, our findings that acute high doses of $17 \beta$-estradiol blocked the effects of amphetamine as well as potentiated LI on its own support the notion that $17 \beta$-estradiol reduces mesolimbic DA function. Taken together, the efficacy of $17 \beta$-estradiol to alleviate nonpharmacologically and pharmacologically induced LI disruption is indicative of its therapeutic capacity for positive symptoms in schizophrenia.

Previous studies showed that in OVX rats, $17 \beta$-estradiol can reverse psychosis-mimicking abnormalities induced by dopamine agonists, including hyperactivity, stereotypy and circling (Becker and Beer, 1986; Becker and Rudick, 1999; Bedard et al, 1983; Bedard et al, 1978; Earley and Leonard, 1978; Euvrard et al, 1979; Euvrard et al, 1980; Gordon, 1980; Gordon and Diamond, 1981; Naik et al, 1978), disrupted PPI (Gogos et al, 2010), and disrupted LI (Arad and Weiner, $2009,2010)$. To the best of our knowledge, this is the first demonstration that $17 \beta$-estradiol exerts an antipsychotic action in gonadally intact rats of both sexes. These outcomes indicate that $17 \beta$-estradiol possesses antipsychotic properties in both sexes and, by extension, that such action is independent of endogenous estrogen levels.

\section{Reversal of Abnormally Persistent LI: Putative Efficacy for Negative and Cognitive Symptoms}

As NMDA antagonists induce in addition to positive symptoms, also negative symptoms and cognitive impairments characteristic of endogenous schizophrenia (Javitt and Zukin, 1991; Krystal et al, 2003; Lahti et al, 1995; Malhotra et al, 1997; Tamminga, 1998), their behavioral effects in animals, with the exception of locomotor hyperactivity, are usually used as pharmacological models of negative and/or cognitive symptoms (Bakshi et al, 1994; Javitt and Zukin, 1991; Moghaddam and Jackson, 2003; Nilsson et al, 2001; Sams-Dodd, 1996; Swerdlow et al, 1996). Cognitive and behavioral inflexibility that is often observed following NMDA blockade in rats and humans has been argued to be particularly relevant to the modeling of negative/cognitive symptoms (Carlsson et al, 1999; Carlsson and Carlsson, 1990b; Krystal et al, 2000; Moghaddam et al, 1997).

As shown previously (Gaisler-Salomon et al, 2008; Gaisler-Salomon and Weiner, 2003; Lipina et al, 2005), under strong conditioning, MK-801 induced persistent LI in male rats. In other words, whereas vehicle-injected PE male rats switched in the conditioning stage to respond according to the stimulus-reinforcement contingency, MK-801injected PE rats persisted in responding according to the stimulus-no-event contingency acquired in pre-exposure, in line with many findings showing that NMDA receptor blockade induces behavioral and cognitive inflexibility (Carlsson and Carlsson, 1990a; Jentsch and Taylor, 2001; Moghaddam et al, 1997; Svensson, 2000; van der Meulen et al, 2003). The same effect of MK-801 on LI was shown here, for the first time, in gonadally intact and OVX females. Thus, like amphetamine, MK-801 produced its schizophrenia- relevant effect in a sex-independent manner. However, unlike amphetamine-induced disrupted LI, in gonadally intact rats, MK-801-induced persistent LI was ameliorated by $17 \beta$-estradiol in male but not female rats. The latter is rather remarkable as it suggests that $17 \beta$-estradiol is more efficient in ameliorating MK-801 effects on LI in the absence of estrogen. This suggestion was supported by our finding that $17 \beta$-estradiol was also effective in reversing MK-801induced persistent LI in OVX rats. The basis for the sexdependent sensitivity of MK-801-induced persistent LI to $17 \beta$-estradiol in gonadally intact rats is unclear. Greater sensitivity of gonadally intact females than males to NMDA antagonists, such as MK-801, requiring higher $17 \beta$-estradiol doses to block its effects, has been reported but for much higher, neurodegeneration-producing MK-801 doses (Andine et al, 1999; Auer, 1996; de Olmos et al, 2008; Dribben et al, 2003; Fix et al, 1995; Honack and Loscher, 1993; Wozniak et al, 1998). The sex-dependent effects might also be dependent on the behavioral phenomenon tested, as $17 \beta$-estradiol was found to reverse the disruptive effects of the NMDA antagonist PCP in the novel object-recognition test in gonadally intact female rats (Sutcliffe et al, 2007).

The mechanism/s by which $17 \beta$-estradiol reverses MK801-induced persistence of LI remain to be investigated, but two options can be suggested based on known pharmacological reversals of this abnormality. Reversal of MK-801induced persistent LI by atypical APDs is mediated by $5 \mathrm{HT}_{2 \mathrm{~A}}$ receptor antagonism (Gaisler-Salomon and Weiner, 2003; Weiner and Arad, 2009). In addition, MK-801-induced persistent LI is reversed by a wide variety of compounds enhancing NMDA receptor function (Black et al, 2009; Gaisler-Salomon et al, 2008).

The relationship between estrogen and serotonin is well documented. Studies in intact rats of both sexes have shown that estrogen modulates brain serotonergic activity (Fink et al, 1998) and that during high estrogen levels, $5 \mathrm{HT}_{2 \mathrm{~A}}$ density is increased (Sumner and Fink 1997). 17 $\beta$-estradiol treatment in gonadectomized female and male rats increased $5 \mathrm{HT}_{2 \mathrm{~A}}$ mRNA levels and receptors' density in the frontal cortex and NAC (Cyr et al, 1998; Fink et al, 1998; Summer and Fink, 1995; Sumner and Fink, 1998). Importantly, the same effect is produced in intact male rats by clozapine (Buckland et al, 1997). Clinical studies reported that raloxifene, a second generation selective estrogen receptor modulator, mimics $17 \beta$-estradiol effect on $5 \mathrm{HT}_{2 \mathrm{~A}}$ receptor binding by increasing $5 \mathrm{HT}_{2 \mathrm{~A}}$ receptor binding levels and its mRNA levels in the frontal cortex, amygdala, NAC, and striatum (Cyr et al, 2002).

There is also a well-established relationship between estrogen and NMDA receptor function. In OVX rats, $17 \beta$ estradiol increases hippocampal NMDA receptors and glutamate transmission, whereas in the striatum, frontal cortex, and NAC, $17 \beta$-estradiol decreases NMDA receptor binding. Furthermore, $17 \beta$-estradiol increases agonist binding but decreases antagonist binding of NMDA receptors in the hippocampus (Cyr et al, 2000; Cyr et al, 2001; Daniel and Dohanich, 2001; El-Bakri et al, 2004; Gazzaley et al, 1996; Weiland, 1992; Woolley and Schwartzkroin, 1998; Woolley et al, 1997). Although these effects could explain the reversal of MK-801-induced persistent LI in OVX rats seen here, it is not clear whether similar effects are exerted in intact male brains. However, 
$17 \beta$-estradiol does enhance glutamatergic transmission in hippocampal slices taken from male rats (Teyler et al, 1980).

\section{$17 \beta$-Estradiol in LI-An Antipsychotic with a Sex-Dependent Action}

Although the mechanisms underlying the effects of $17 \beta$ estradiol seen here remain to be investigated, our results show that at certain doses this agent possesses an antipsychotic profile in the LI model. Moreover, this profile is sex dependent. Specifically, $17 \beta$-estradiol possesses a profile of a typical APD (consisting of LI potentiation on its own and reversal of amphetamine-induced LI disruption) in both sexes and a profile of an atypical APD (consisting of LI potentiation on its own, reversal of amphetamine-induced disrupted LI and reversal of MK801-induced persistent LI), in male rats.

In psychological terms, in all of the models, $17 \beta$-estradiol targeted selectively the processes responsible for attentional selectivity (in the PE groups) without affecting associative capacity (in the NPE groups). Furthermore, reversal of disrupted and persistent LI can be seen as normalization of two poles of dysfunctional attentional control. On the one hand, $17 \beta$-estradiol strengthens/restores the capacity to ignore irrelevant stimuli in amphetamine-treated rats and on the other hand, $17 \beta$-estradiol strengthens/restores the capacity to dis-ignore irrelevant stimuli when they become relevant, enabling flexible re-deployment of attentional resources according to current situational demands, in MK-801-treated rats. The former would be beneficial in normalizing aberrantly increased salience perception and distractibility that are associated with psychotic symptoms (Gray et al, 1991; Kapur, 2003; Smith et al, 2006; Swerdlow and Koob, 1987; Weiner and Joel, 2002), whereas the latter would be beneficial in reducing cognitive inflexibility and inattention that are associated with negative/cognitive symptoms (Carlsson and Carlsson, 1990b; Krystal et al, 2003; Moghaddam et al, 1997; Weiner, 2003). Given that $17 \beta$-estradiol reverses amphetamine-induced LI disruption in both sexes, but MK-801-induced LI persistence only in male and OVX rats, the implications of our results for the clinic are that $17 \beta$-estradiol would be beneficial against positive symptoms in both sexes but against negative/ cognitive symptoms in male patients and in women with very low estrogen levels, eg, during menopause.

This conclusion seems in line with positive reports from the clinic. Efficacy of $17 \beta$-estradiol against positive symptoms in schizophrenic women has been shown in several studies (Kulkarni et al, 2008a; Kulkarni et al, 1996; Kulkarni et al, 2008b; Kulkarni et al, 2001; Riecher-Rossler and de Geyter, 2007), as it was reported to be less effective or ineffective against negative symptoms (Akhondzadeh et al, 2003; Kulkarni et al, 2008a). In an attempt to reconcile inconsistent reports in the literature regarding efficacy of estradiol treatment in schizophrenic women, Mortimer (2007) suggested that such treatment would be effective in schizophrenic women who suffer from severe estrogen deficiency. Interestingly, reduced levels of plasma estrogen were found in both male (Huber et al, 2005) and female (Bergemann et al, 2005; Huber et al, 2004; Huber et al, 2001; Riecher-Rossler et al, 1994) schizophrenia patients, and recently a small study of men with schizophrenia who received oral estradiol valerate also showed an abatement in psychotic symptoms (Kulkarni, 2009). The role of estrogen in schizophrenia has been supported by the finding that variation in the estrogen receptor alpha gene and cortical estrogen receptor alpha mRNA is associated with schizophrenia (Perlman et al, 2005; Perlman et al, 2004; Weickert et al, 2008; Wong and Weickert, 2009) and it has been suggested that the brain response to circulating estrogen may be altered in schizophrenia (Weickert et al, 2008). Taken together with our animal data, estrogen seems to have the potential to be useful in the treatment of schizophrenia.

In summary, our previous (Arad and Weiner, 2010) and present data are clear in showing that estrogen can exert antipsychotic activity, reversing hyperdopaminergia-induced behavioral abnormality in gonadally intact rats of both sexes and in OVX rats, and reversing hypoglutamatergia-induced abnormality in male and OVX rats. By extension, these results suggest that estrogen can be viewed as an effective treatment not only for positive symptoms in women with schizophrenia, but also for a wide spectrum of symptoms in women and men with schizophrenia, including negative/cognitive symptoms. Unfortunately, the risk of inducing cancers has limited the applicability of estrogen in humans for use in modulating the central nervous system neurotransmission (Rossouw et al, 2002), although recent studies found no increased risk (Anderson et al, 2006; Stefanick et al, 2006; Stevenson, 2009). Importantly in this context, our previous data showed that co-administration of a physiological dose of $17 \beta$-estradiol and APD augments APD efficacy, and in fact may be more effective than raising the dose of APD. Further research is required to determine the correct dose and duration of the use of $17 \beta$-estradiol as monotherapy, as well as an adjunctive therapy. Our present results raise the possibility that variable outcomes in the clinic may be because of the differences in the dosage of estrogen and, in general, alert to the importance of doseresponse studies. Finally, new estrogenic compounds acting selectively in the brain may provide a safer, non-feminizing approach for the treatment of schizophrenia (Cyr et al, 2002; Kulkarni, 2009).

\section{ACKNOWLEDGEMENTS}

We wish to thank the Joseph Sagol Fellowship Program in Humanities and Social Sciences at Tel-Aviv University for their funding (MA).

\section{DISCLOSURE}

The authors declare no conflict of interest.

\section{REFERENCES}

Akhondzadeh S, Nejatisafa AA, Amini H, Mohammadi MR, Larijani B, Kashani L et al (2003). Adjunctive estrogen treatment in women with chronic schizophrenia: a double-blind, randomized, and placebo-controlled trial. Prog Neuropsychopharmacol Biol Psychiatry 27: 1007-1012.

Anderson GL, Chlebowski RT, Rossouw JE, Rodabough RJ, McTiernan A, Margolis KL et al (2006). Prior hormone therapy and breast cancer risk in the Women's Health Initiative 
randomized trial of estrogen plus progestin. Maturitas 55: 103-115.

Andine P, Widermark N, Axelsson R, Nyberg G, Olofsson U, Martensson E et al (1999). Characterization of MK-801-induced behavior as a putative rat model of psychosis. J Pharmacol Exp Ther 290: 1393-1408.

Arad M, Weiner I (2008). Fluctuation of latent inhibition along the estrous cycle in the rat: modeling the cyclicity of symptoms in schizophrenic women? Psychoneuroendocrinology 33: 1401-1410.

Arad M, Weiner I (2009). Disruption of latent inhibition induced by ovariectomy can be reversed by estradiol and clozapine as well as by co-administration of haloperidol with estradiol but not by haloperidol alone. Psychopharmacology (Berl) 206: 731-740.

Arad M, Weiner I (2010). Contrasting effects of increased and decreased dopamine transmission on latent inhibition in ovariectomized rats and their modulation by 17beta-estradiol: an animal model of menopausal psychosis? Neuropsychopharmacology 35: 1570-1582.

Arvin M, Fedorkova L, Disshon KA, Dluzen DE, Leipheimer RE (2000). Estrogen modulates responses of striatal dopamine neurons to $\mathrm{MPP}(+)$ : evaluations using in vitro and in vivo techniques. Brain Res 872: 160-171.

Auer RN (1996). Effect of age and sex on N-methyl-Daspartate antagonist-induced neuronal necrosis in rats. Stroke 27: 743-746.

Bakshi VP, Swerdlow NR, Geyer MA (1994). Clozapine antagonizes phencyclidine-induced deficits in sensorimotor gating of the startle response. J Pharmacol Exp Ther 271: 787-794.

Barak S, Arad M, De Levie A, Black MD, Griebel G, Weiner I (2009). Pro-cognitive and antipsychotic efficacy of the alpha7 nicotinic partial agonist SSR180711 in pharmacological and neurodevelopmental latent inhibition models of schizophrenia. Neuropsychopharmacology 34: 1753-1763.

Barber PV, Arnold AG, Evans G (1976). Recurrent hormone dependent chorea: effects of oestrogens and progestogens. Clin Endocrinol (Oxf) 5: 291-293.

Barch DM, Carter CS (2008). Measurement issues in the use of cognitive neuroscience tasks in drug development for impaired cognition in schizophrenia: a report of the second consensus building conference of the CNTRICS initiative. Schizophr Bull 34: 613-618.

Barnes P, Staal V, Muir J, Good MA (2006). 17-beta estradiol administration attenuates deficits in sustained and divided attention in young ovariectomized rats and aged acyclic female rats. Behav Neurosci 120: 1225-1234.

Barrett SL, Bell R, Watson D, King DJ (2004). Effects of amisulpride, risperidone and chlorpromazine on auditory and visual latent inhibition, prepulse inhibition, executive function and eye movements in healthy volunteers. J Psychopharmacol 18: $156-172$.

Baruch I, Hemsley DR, Gray JA (1988). Differential performance of acute and chronic schizophrenics in a latent inhibition task. J Nerv Ment Dis 176: 598-606.

Becker JB (1999). Gender differences in dopaminergic function in striatum and nucleus accumbens. Pharmacol Biochem Behav 64: 803-812.

Becker JB, Beer ME (1986). The influence of estrogen on nigrostriatal dopamine activity: behavioral and neurochemical evidence for both pre- and postsynaptic components. Behav Brain Res 19: 27-33.

Becker JB, Rudick CN (1999). Rapid effects of estrogen or progesterone on the amphetamine-induced increase in striatal dopamine are enhanced by estrogen priming: a microdialysis study. Pharmacol Biochem Behav 64: 53-57.
Bedard P, Boucher R, Di Paolo T, Labrie F (1983). Biphasic effect of estradiol and domperidone on lingual dyskinesia in monkeys. Exp Neurol 82: 172-182.

Bedard P, Dankova J, Boucher R, Langelier P (1978). Effect of estrogens on apomorphine-induced circling behavior in the rat. Can J Physiol Pharmacol 56: 538-541.

Bedard P, Langelier P, Villeneuve A (1977). Oestrogens and extrapyramidal system. Lancet 2: 1367-1368.

Bedard PJ, Malouin F, Dipaolo T, Labrie F (1982). Estradiol, TRH and striatal dopaminergic mechanisms. Prog Neuropsychopharmacol Biol Psychiatry 6: 555-561.

Bergemann N, Mundt C, Parzer P, Pakrasi M, Eckstein-Mannsperger U, Haisch S et al (2005). Estrogen as an adjuvant therapy to antipsychotics does not prevent relapse in women suffering from schizophrenia: results of a placebo-controlled double-blind study. Schizophr Res 74: 125-134.

Black MD, Varty GB, Arad M, Barak S, De Levie A, Boulay D et al (2008). Procognitive and antipsychotic efficacy of glycine transport 1 inhibitors (GlyT1) in acute and neurodevelopmental models of schizophrenia: latent inhibition studies in the rat. Psychopharmacology (Berl) 202: 385-396.

Black MD, Varty GB, Arad M, Barak S, De Levie A, Boulay D et al (2009). Procognitive and antipsychotic efficacy of glycine transport 1 inhibitors (GlyT1) in acute and neurodevelopmental models of schizophrenia: latent inhibition studies in the rat. Psychopharmacology (Berl) 202: 385-396.

Braunstein-Bercovitz H, Rammsayer T, Gibbons H, Lubow RE (2002). Latent inhibition deficits in high-schizotypal normals: symptom-specific or anxiety-related? Schizophr Res 53: 109-121.

Buckland PR, D'Souza U, Maher NA, McGuffin P (1997). The effects of antipsychotic drugs on the mRNA levels of serotonin 5HT2A and 5HT2C receptors. Brain Res Mol Brain Res 48: 45-52.

Carlsson A, Waters N, Carlsson ML (1999). Neurotransmitter interactions in schizophrenia-therapeutic implications. Biol Psychiatry 46: 1388-1395.

Carlsson M, Carlsson A (1990a). Interactions between glutamatergic and monoaminergic systems within the basal ganglia-implications for schizophrenia and Parkinson's disease. Trends Neurosci 13: 272-276.

Carlsson M, Carlsson A (1990b). Schizophrenia: a subcortical neurotransmitter imbalance syndrome? Schizophr Bull 16: 425-432.

Chavez C, Gogos A, Jones ME, van den Buuse M (2009). Psychotropic drug-induced locomotor hyperactivity and prepulse inhibition regulation in male and female aromatase knockout (ArKO) mice: role of dopamine D1 and D2 receptors and dopamine transporters. Psychopharmacology (Berl) 206: 267-279.

Chavez C, Hollaus M, Scarr E, Pavey G, Gogos A, van den Buuse M (2010). The effect of estrogen on dopamine and serotonin receptor and transporter levels in the brain: an autoradiography study. Brain Res 1321: 51-59.

Chiodo LA, Caggiula AR, Saller CF (1979). Estrogen increases both spiperone-induced catalepsy and brain levels of $[3 \mathrm{H}]$ spiperone in the rat. Brain Res 172: 360-366.

Cyr M, Bosse R, Di Paolo T (1998). Gonadal hormones modulate 5hydroxytryptamine $2 \mathrm{~A}$ receptors: emphasis on the rat frontal cortex. Neuroscience 83: 829-836.

Cyr M, Calon F, Morissette M, Di Paolo T (2002). Estrogenic modulation of brain activity: implications for schizophrenia and Parkinson's disease. J Psychiatry Neurosci 27: 12-27.

Cyr M, Ghribi O, Di Paolo T (2000). Regional and selective effects of oestradiol and progesterone on NMDA and AMPA receptors in the rat brain. J Neuroendocrinol 12: 445-452.

Cyr M, Ghribi O, Thibault C, Morissette M, Landry M, Di Paolo T (2001). Ovarian steroids and selective estrogen receptor modulators activity on rat brain NMDA and AMPA receptors. Brain Res Brain Res Rev 37: 153-161. 
Daniel JM, Bohacek J (2010). The critical period hypothesis of estrogen effects on cognition: insights from basic research. Biochim Biophys Acta (e pub ahead of print).

Daniel JM, Dohanich GP (2001). Acetylcholine mediates the estrogen-induced increase in NMDA receptor binding in CA1 of the hippocampus and the associated improvement in working memory. J Neurosci 21: 6949-6956.

de Olmos S, Bueno A, Bender C, Lorenzo A, de Olmos J (2008). Sex differences and influence of gonadal hormones on MK801induced neuronal degeneration in the granular retrosplenial cortex of the rat. Brain Struct Funct 213: 229-238.

De Ryck M, Hruska RE, Silbergeld EK (1982). Estrogen and haloperidol-induced versus handling-related catalepsy in male rats. Pharmacol Biochem Behav 17: 1027-1035.

Di Paolo T (1994). Modulation of brain dopamine transmission by sex steroids. Rev Neurosci 5: 27-41.

Di Paolo T, Carmichael R, Labrie F, Raynaud JP (1979). Effects of estrogens on the characteristics of $[3 \mathrm{H}]$ spiroperidol and [3H]RU24213 binding in rat anterior pituitary gland and brain. Mol Cell Endocrinol 16: 99-112.

Di Paolo T, Poyet P, Labrie F (1981). Effect of chronic estradiol and haloperidol treatment on striatal dopamine receptors. Eur $J$ Pharmacol 73: 105-106.

Disshon KA, Boja JW, Dluzen DE (1998). Inhibition of striatal dopamine transporter activity by 17beta-estradiol. Eur $J$ Pharmacol 345: 207-211.

Dluzen D, Horstink M (2003). Estrogen as neuroprotectant of nigrostriatal dopaminergic system: laboratory and clinical studies. Endocrine 21: 67-75.

Dribben W, Nemmers B, Nardi A, Taylor G, Olney J, Farber N (2003). Chronic but not acute estradiol treatment protects against the neurodegenerative effects of $N$-methyl-D-aspartate receptor antagonists. Endocrine 21: 53-58.

Dunn LA, Atwater GE, Kilts CD (1993). Effects of antipsychotic drugs on latent inhibition: sensitivity and specificity of an animal behavioral model of clinical drug action. Psychopharmacology (Berl) 112: 315-323.

Earley CJ, Leonard BE (1978). Behavioural studies on the effects of d-amphetamine and estradiol benzoate alone and in combination. Psychopharmacology (Berl) 56: 179-183.

El-Bakri NK, Islam A, Zhu S, Elhassan A, Mohammed A, Winblad B et al (2004). Effects of estrogen and progesterone treatment on rat hippocampal NMDA receptors: relationship to Morris water maze performance. J Cell Mol Med 8: 537-544.

Euvrard C, Labrie F, Boissier JR (1979). Effect of moxestrol on haloperidol-induced changes in striatal acetylcholine levels and dopamine turn-over. Commun Psychopharmacol 3: 329-334.

Euvrard C, Oberlander C, Boissier JR (1980). Antidopaminergic effect of estrogens at the striatal level. J Pharmacol Exp Ther 214: 179-185.

Fattore L, Altea S, Fratta W (2008). Sex differences in drug addiction: a review of animal and human studies. Womens Health (Lond Engl) 4: 51-65.

Fink G, Sumner BE, McQueen JK, Wilson H, Rosie R (1998). Sex steroid control of mood, mental state and memory. Clin Exp Pharmacol Physiol 25: 764-775.

Fix AS, Wozniak DF, Truex LL, McEwen M, Miller JP, Olney JW (1995). Quantitative analysis of factors influencing neuronal necrosis induced by MK-801 in the rat posterior cingulate/ retrosplenial cortex. Brain Res 696: 194-204.

Frick KM (2009). Estrogens and age-related memory decline in rodents: what have we learned and where do we go from here? Horm Behav 55: 2-23.

Gaisler-Salomon I, Diamant L, Rubin C, Weiner I (2008). Abnormally persistent latent inhibition induced by MK801 is reversed by risperidone and by positive modulators of NMDA receptor function: differential efficacy depending on the stage of the task at which they are administered. Psychopharmacology (Berl) 196: 255-267.

Gaisler-Salomon I, Weiner I (2003). Systemic administration of MK-801 produces an abnormally persistent latent inhibition which is reversed by clozapine but not haloperidol. Psychopharmacology (Berl) 166: 333-342.

Galea LA, Wide JK, Barr AM (2001). Estradiol alleviates depressive-like symptoms in a novel animal model of postpartum depression. Behav Brain Res 122: 1-9.

Gazzaley AH, Weiland NG, McEwen BS, Morrison JH (1996). Differential regulation of NMDAR1 mRNA and protein by estradiol in the rat hippocampus. J Neurosci 16: 6830-6838.

Gibbs RB, Burke AM, Johnson DA (1998). Estrogen replacement attenuates effects of scopolamine and lorazepam on memory acquisition and retention. Horm Behav 34: 112-125.

Gogos A, Kwek P, Chavez C, van den Buuse M (2010). Estrogen treatment blocks 8-hydroxy-2-dipropylaminotetralin- and apomorphine-induced disruptions of prepulse inhibition: involvement of dopamine D1 or D2 or serotonin 5-HT1A, 5-HT2A, or 5-HT7 receptors. J Pharmacol Exp Ther 333: 218-227.

Gogos A, Nathan PJ, Guille V, Croft RJ, van den Buuse M (2006). Estrogen prevents 5-HT1A receptor-induced disruptions of prepulse inhibition in healthy women. Neuropsychopharmacology 31: 885-889.

Gordon JH (1980). Modulation of apomorphine-induced stereotypy by estrogen: time course and dose response. Brain Res Bull 5: 679-682.

Gordon JH, Diamond BI (1981). Antagonism of dopamine supersensitivity by estrogen: neurochemical studies in an animal model of tardive dyskinesia. Biol Psychiatry 16: 365-371.

Gray JA, Feldon J, Rawlins JNP, Hemsley DR, Smith AD (1991). The neuropsychology of schizophrenia. Behav Brain Sci 14: $1-84$.

Gray JA, Joseph MH, Hemsley DR, Young AM, Warburton EC, Boulenguez $\mathrm{P}$ et al (1995a). The role of mesolimbic dopaminergic and retrohippocampal afferents to the nucleus accumbens in latent inhibition: implications for schizophrenia. Behav Brain Res 71: 19-31.

Gray JA, Moran PM, Grigoryan G, Peters SL, Young AM, Joseph MH (1997). Latent inhibition: the nucleus accumbens connection revisited. Behav Brain Res 88: 27-34.

Gray NS, Hemsley DR, Gray JA (1992a). Abolition of latent inhibition in acute, but not chronic, schizophrenics. Neurol Psychiatr Brain res 1: 83-89.

Gray NS, Pickering AD, Hemsley DR, Dawling S, Gray JA (1992b). Abolition of latent inhibition by a single $5 \mathrm{mg}$ dose of d-amphetamine in man. Psychopharmacology (Berl) 107: 425-430.

Gray NS, Pilowsky LS, Gray JA, Kerwin RW (1995b). Latent inhibition in drug naive schizophrenics: relationship to duration of illness and dopamine D2 binding using SPET. Schizophr Res 17: 95-107.

Hafner H (2003). Gender differences in schizophrenia. Psychoneuroendocrinology 28(Suppl 2): 17-54.

Hafner H, Behrens S, De Vry J, Gattaz WF (1991). An animal model for the effects of estradiol on dopamine-mediated behavior: implications for sex differences in schizophrenia. Psychiatry Res 38: $125-134$.

Hafner H, Riecher A, Maurer K, Loffler W, Munk-Jorgensen P, Stromgren E (1989). How does gender influence age at first hospitalization for schizophrenia? A transnational case register study. Psychol Med 19: 903-918.

Harvey PD, Rabinowitz J, Eerdekens M, Davidson M (2005). Treatment of cognitive impairment in early psychosis: a comparison of risperidone and haloperidol in a large long-term trial. Am J Psychiatry 162: 1888-1895.

Heresco-Levy U, Javitt DC, Ebstein R, Vass A, Lichtenberg P, Bar G et al (2005). D-serine efficacy as add-on pharmacotherapy to 
risperidone and olanzapine for treatment-refractory schizophrenia. Biol Psychiatry 57: 577-585.

Honack D, Loscher W (1993). Sex differences in NMDA receptor mediated responses in rats. Brain Res 620: 167-170.

Hruska RE, Silbergeld EK (1980). Increased dopamine receptor sensitivity after estrogen treatment using the rat rotation model. Science 208: 1466-1468.

Huber TJ, Borsutzky M, Schneider U, Emrich HM (2004). Psychotic disorders and gonadal function: evidence supporting the oestrogen hypothesis. Acta Psychiatr Scand 109: 269-274.

Huber TJ, Rollnik J, Wilhelms J, von zur Muhlen A, Emrich HM, Schneider U (2001). Estradiol levels in psychotic disorders. Psychoneuroendocrinology 26: 27-35.

Huber TJ, Tettenborn C, Leifke E, Emrich HM (2005). Sex hormones in psychotic men. Psychoneuroendocrinology 30: 111-114.

Javitt DC, Zukin SR (1991). Recent advances in the phencyclidine model of schizophrenia. Am J Psychiatry 148: 1301-1308.

Jentsch JD, Taylor JR (2001). Impaired inhibition of conditioned responses produced by subchronic administration of phencyclidine to rats. Neuropsychopharmacology 24: 66-74.

Joseph MH, Peters SL, Moran PM, Grigoryan GA, Young AM, Gray JA (2000). Modulation of latent inhibition in the rat by altered dopamine transmission in the nucleus accumbens at the time of conditioning. Neuroscience 101: 921-930.

Kapur S (2003). Psychosis as a state of aberrant salience: a framework linking biology, phenomenology, and pharmacology in schizophrenia. Am J Psychiatry 160: 13-23.

Kapur S, Mizrahi R, Li M (2005). From dopamine to salience to psychosis - linking biology, pharmacology and phenomenology of psychosis. Schizophr Res 79: 59-68.

Kitamura N, Araya R, Kudoh M, Kishida H, Kimura T, Murayama $M$ et al (2009). Beneficial effects of estrogen in a mouse model of cerebrovascular insufficiency. PLoS One 4: e5159.

Korhonen S, Saarijarvi S, Aito M (1995). Successful estradiol treatment of psychotic symptoms in the premenstrual phase: a case report. Acta Psychiatr Scand 92: 237-238.

Krystal JH, Bennett A, Abi-Saab D, Belger A, Karper LP, D'Souza DC et al (2000). Dissociation of ketamine effects on rule acquisition and rule implementation: possible relevance to NMDA receptor contributions to executive cognitive functions. Biol Psychiatry 47: 137-143.

Krystal JH, D'Souza DC, Mathalon D, Perry E, Belger A, Hoffman R (2003). NMDA receptor antagonist effects, cortical glutamatergic function, and schizophrenia: toward a paradigm shift in medication development. Psychopharmacology (Berl) 169: 215-233.

Kulkarni J (2009). Oestrogen - a new treatment approach for schizophrenia? Med J Aust 190: S37-S38.

Kulkarni J, de Castella A, Fitzgerald PB, Gurvich CT, Bailey M, Bartholomeusz C et al (2008a). Estrogen in severe mental illness: a potential new treatment approach. Arch Gen Psychiatry 65: 955-960.

Kulkarni J, de Castella A, Smith D, Taffe J, Keks N, Copolov D (1996). A clinical trial of the effects of estrogen in acutely psychotic women. Schizophr Res 20: 247-252.

Kulkarni J, Gurvich C, Gilbert H, Mehmedbegovic F, Mu L, Marston $\mathrm{N}$ et al (2008b). Hormone modulation: a novel therapeutic approach for women with severe mental illness. Aust N Z J Psychiatry 42: 83-88.

Kulkarni J, Riedel A, de Castella AR, Fitzgerald PB, Rolfe TJ, Taffe J et al (2001). Estrogen - a potential treatment for schizophrenia. Schizophr Res 48: 137-144.

Lahti AC, Koffel B, LaPorte D, Tamminga CA (1995). Subanesthetic doses of ketamine stimulate psychosis in schizophrenia. Neuropsychopharmacology 13: 9-19.

Lipina T, Labrie V, Weiner I, Roder J (2005). Modulators of the glycine site on NMDA receptors, D: -serine and ALX 5407, display similar beneficial effects to clozapine in mouse models of schizophrenia. Psychopharmacology (Berl) 179: 54-67.

Lubow RE. Latent Inhibition and Conditioned Attention Theory. Cambridge University Press: Cambridge University Press, 1989.

Mackintosh NJ (1975). A theory of attention: Variations in the associability of stimuli with reinforcement. Psychol Rev 82: 276-298.

Malhotra AK, Pinals DA, Adler CM, Elman I, Clifton A, Pickar D et al (1997). Ketamine-induced exacerbation of psychotic symptoms and cognitive impairment in neuroleptic-free schizophrenics. Neuropsychopharmacology 17: 141-150.

Marcondes FK, Bianchi FJ, Tanno AP (2002). Determination of the estrous cycle phases of rats: some helpful considerations. Braz J Biol 62: 609-614.

McCartan D, Bell R, Green JF, Campbell C, Trimble K, Pickering A et al (2001). The differential effects of chlorpromazine and haloperidol on latent inhibition in healthy volunteers. J Psychopharmacol 15: 96-104.

McDermott JL (1993). Effects of estrogen upon dopamine release from the corpus striatum of young and aged female rats. Brain Res 606: 118-125.

McEwen BS, Alves SE (1999). Estrogen actions in the central nervous system. Endocr Rev 20: 279-307.

Moghaddam B, Adams B, Verma A, Daly D (1997). Activation of glutamatergic neurotransmission by ketamine: a novel step in the pathway from NMDA receptor blockade to dopaminergic and cognitive disruptions associated with the prefrontal cortex. J Neurosci 17: 2921-2927.

Moghaddam B, Jackson ME (2003). Glutamatergic animal models of schizophrenia. Ann N Y Acad Sci 1003: 131-137.

Morissette M, Al Sweidi S, Callier S, Di Paolo T (2008). Estrogen and SERM neuroprotection in animal models of Parkinson's disease. Mol Cell Endocrinol 290: 60-69.

Morissette M, Di Paolo T (1993). Effect of chronic estradiol and progesterone treatments of ovariectomized rats on brain dopamine uptake sites. J Neurochem 60: 1876-1883.

Mortimer AM (2007). Relationship between estrogen and schizophrenia. Expert Rev Neurother 7: 45-55.

Naik SR, Kelkar MR, Sheth UK (1978). Attenuation of stereotyped behaviour by sex steroids. Psychopharmacology (Berl) 57: 211-214.

Nicoletti F, Ferrara N, Patti F, Viglianesi M, Rampello L, Bianchi A et al (1983). Influence of sex steroids and prolactin on haloperidol-induced catalepsy. Brain Res 279: 352-358.

Nilsson M, Waters S, Waters N, Carlsson A, Carlsson ML (2001). A behavioural pattern analysis of hypoglutamatergic mice-effects of four different antipsychotic agents. J Neural Transm 108: 1181-1196.

Nofrey BS, Ben-Shahar OM, Brake WG (2008). Estrogen abolishes latent inhibition in ovariectomized female rats. Brain Cogn 66: $156-160$

Packard MG, Kohlmaier JR, Alexander GM (1996). Posttraining intrahippocampal estradiol injections enhance spatial memory in male rats: interaction with cholinergic systems. Behav Neurosci 110: 626-632.

Palermo-Neto J, Dorce VA (1990). Influences of estrogen and/or progesterone on some dopamine related behavior in rats. Gen Pharmacol 21: 83-87.

Palsson E, Klamer D, Wass C, Archer T, Engel JA, Svensson L (2005). The effects of phencyclidine on latent inhibition in taste aversion conditioning: differential effects of preexposure and conditioning. Behav Brain Res 157: 139-146.

Peris J, Decambre N, Coleman-Hardee ML, Simpkins JW (1991). Estradiol enhances behavioral sensitization to cocaine and amphetamine-stimulated striatal $[3 \mathrm{H}]$ dopamine release. Brain Res 566: 255-264. 
Perlman WR, Tomaskovic-Crook E, Montague DM, Webster MJ, Rubinow DR, Kleinman JE et al (2005). Alteration in estrogen receptor alpha mRNA levels in frontal cortex and hippocampus of patients with major mental illness. Biol Psychiatry 58: 812-824.

Perlman WR, Webster MJ, Kleinman JE, Weickert CS (2004). Reduced glucocorticoid and estrogen receptor alpha messenger ribonucleic acid levels in the amygdala of patients with major mental illness. Biol Psychiatry 56: 844-852.

Rascle C, Mazas O, Vaiva G, Tournant M, Raybois O, Goudemand M et al (2001). Clinical features of latent inhibition in schizophrenia. Schizophr Res 51: 149-161.

Riddoch D, Jefferson M, Bickerstaff ER (1971). Chorea and the oral contraceptives. $\mathrm{Br}$ Med J 4: 217-218.

Riecher-Rossler A (2002). Oestrogen effects in schizophrenia and their potential therapeutic implications - review. Arch Womens Ment Health 5: 111-118.

Riecher-Rossler A, de Geyter C (2007). The forthcoming role of treatment with oestrogens in mental health. Swiss Med Wkly 137: $565-572$.

Riecher-Rossler A, Hafner H (1993). Schizophrenia and oestrogens - is there an association? Eur Arch Psychiatry Clin Neurosci 242: 323-328.

Riecher-Rossler A, Hafner H, Stumbaum M, Maurer K, Schmidt R (1994). Can estradiol modulate schizophrenic symptomatology? Schizophr Bull 20: 203-214.

Rossouw JE, Anderson GL, Prentice RL, LaCroix AZ, Kooperberg C, Stefanick ML et al (2002). Risks and benefits of estrogen plus progestin in healthy postmenopausal women: principal results From the Women's Health Initiative randomized controlled trial. JAMA 288: 321-333.

Salgado JV, Hetem LA, Vidal M, Graeff FG, Danion JM, Sandner G (2000). Reduction of latent inhibition by D-amphetamine in a conditioned suppression paradigm in humans. Behav Brain Res 117: 61-67.

Sams-Dodd F (1996). Phencyclidine-induced stereotyped behaviour and social isolation in rats: a possible animal model of schizophrenia. Behav Pharmacol 7: 3-23.

Seeman MV, Lang M (1990). The role of estrogens in schizophrenia gender differences. Schizophr Bull 16: 185-194.

Segarra AC, Agosto-Rivera JL, Febo M, Lugo-Escobar N, Menéndez-Delmestre R, Puig-Ramos A et al (2009). Estradiol: a key biological substrate mediating the response to cocaine in female rats. Horm Behav 58: 33-43.

Shadach E, Feldon J, Weiner I (1999). Clozapine-induced potentiation of latent inhibition is due to its action in the conditioning stage: implications for the mechanism of action of antipsychotic drugs. Int J Neuropsychopharmacol 2: 283-291.

Sherwin BB, Chertkow H, Schipper H, Nasreddine Z (2009). A randomized controlled trial of estrogen treatment in men with mild cognitive impairment. Neurobiol Aging (e pub ahead of print).

Shieh KR, Yang SC (2008). Effects of estradiol on the stimulation of dopamine turnover in mesolimbic and nigrostriatal systems by cocaine- and amphetamine-regulated transcript peptide in female rats. Neuroscience 154: 1589-1597.

Smith A, Li M, Becker S, Kapur S (2006). Dopamine, prediction error and associative learning: a model-based account. Network 17: $61-84$

Soderstrom I, Strand M, Ingridsson AC, Nasic S, Olsson T (2009). 17beta-estradiol and enriched environment accelerate cognitive recovery after focal brain ischemia. Eur J Neurosci 29: $1215-1224$.

Stefanick ML, Anderson GL, Margolis KL, Hendrix SL, Rodabough RJ, Paskett ED et al (2006). Effects of conjugated equine estrogens on breast cancer and mammography screening in postmenopausal women with hysterectomy. JAMA 295: $1647-1657$

Stevenson JC (2009). Hormone replacement therapy and cardiovascular disease revisited. Menopause Int 15: 55-57.

Summer BE, Fink G (1995). Estrogen increases the density of 5-hydroxytryptamine(2A) receptors in cerebral cortex and nucleus accumbens in the female rat. J Steroid Biochem $\mathrm{Mol}$ Biol 54: 15-20.

Sumner BE, Fink G (1997). The density of 5-hydoxytryptamine2A receptors in forebrain is increased at pro-oestrus in intact female rats. Neurosci Lett 234: 7-10.

Sumner BE, Fink G (1998). Testosterone as well as estrogen increases serotonin2A receptor mRNA and binding site densities in the male rat brain. Brain Res Mol Brain Res 59: 205-214.

Sutcliffe JS, Marshall KM, Neill JC (2007). Influence of gender on working and spatial memory in the novel object recognition task in the rat. Behav Brain Res 177: 117-125.

Sutcliffe JS, Rhaman F, Marshall KM, Neill JC (2008). Oestradiol attenuates the cognitive deficit induced by acute phencyclidine treatment in mature female hooded-Lister rats. J Psychopharmacol 22: 918-922.

Svensson TH (2000). Dysfunctional brain dopamine systems induced by psychotomimetic NMDA-receptor antagonists and the effects of antipsychotic drugs. Brain Res Brain Res Rev 31: 320-329.

Swerdlow NR, Bakshi V, Geyer MA (1996). Seroquel restores sensorimotor gating in phencyclidine-treated rats. J Pharmacol Exp Ther 279: 1290-1299.

Swerdlow NR, Koob GF (1987). Dopamine, schizophrenia, mania and depression: toward a unified hypothesis of cortico-striatopallido-thalamic function. Behav Brain Sci 10: 197-245.

Swerdlow NR, Stephany N, Wasserman LC, Talledo J, Sharp R, Auerbach PP (2003). Dopamine agonists disrupt visual latent inhibition in normal males using a within-subject paradigm. Psychopharmacology (Berl) 169: 314-320.

Swerdlow NR, Stephany N, Wasserman LC, Talledo J, Sharp R, Minassian A et al (2005). Intact visual latent inhibition in schizophrenia patients in a within-subject paradigm. Schizophr Res 72: 169-183.

Tamminga CA (1998). Schizophrenia and glutamatergic transmission. Crit Rev Neurobiol 12: 21-36.

Teyler TJ, Vardaris RM, Lewis D, Rawitch AB (1980). Gonadal steroids: effects on excitability of hippocampal pyramidal cells. Science 209: 1017-1018.

Thompson TL, Moss RL (1994). Estrogen regulation of dopamine release in the nucleus accumbens: genomic- and nongenomicmediated effects. J Neurochem 62: 1750-1756.

Thornton JC, Dawe S, Lee C, Capstick C, Corr PJ, Cotter P et al (1996). Effects of nicotine and amphetamine on latent inhibition in human subjects. Psychopharmacology (Berl) 127: 164-173.

Van den Buuse M, Eikelis N (2001). Estrogen increases prepulse inhibition of acoustic startle in rats. Eur J Pharmacol 425: 33-41.

van der Meulen JA, Bilbija L, Joosten RN, de Bruin JP, Feenstra MG (2003). The NMDA-receptor antagonist MK-801 selectively disrupts reversal learning in rats. Neuroreport 14: 2225-2228.

Walf AA, Frye CA (2009). Estradiol reduces anxiety- and depression-like behavior of aged female mice. Physiol Behav 99: 169-174.

Warburton EC, Mitchell SN, Joseph MH (1996). Calcium dependence of sensitised dopamine release in rat nucleus accumbens following amphetamine challenge: implications for the disruption of latent inhibition. Behav Pharmacol 7: 119-129.

Weickert CS, Miranda-Angulo AL, Wong J, Perlman WR, Ward SE, Radhakrishna V et al (2008). Variants in the estrogen receptor alpha gene and its mRNA contribute to risk for schizophrenia. Hum Mol Genet 17: 2293-2309. 
Weiland NG (1992). Estradiol selectively regulates agonist binding sites on the $N$-methyl-D-aspartate receptor complex in the CA1 region of the hippocampus. Endocrinology 131: 662-668.

Weiner I (2003). The 'two-headed' latent inhibition model of schizophrenia: modeling positive and negative symptoms and their treatment. Psychopharmacology (Berl) 169: 257-297.

Weiner I, Arad M (2009). Using the pharmacology of latent inhibition to model domains of pathology in schizophrenia and their treatment. Behav Brain Res 204: 369-386.

Weiner I, Feldon J (1987). Facilitation of latent inhibition by haloperidol in rats. Psychopharmacology (Berl) 91: 248-253.

Weiner I, Joel D (2002). Dopamine in schizophrenia: dysfunctional information processing in basal ganglia-thalamocortical split circuits. In: Di Chiara G (ed). Handbook of Experimental Pharmacology. Springer: Berlin. pp 418-472.

Weiner I, Schiller D, Gaisler-Salomon I (2003). Disruption and potentiation of latent inhibition by risperidone: the latent inhibition model of atypical antipsychotic action. Neuropsychopharmacology 28: 499-509.

Williams JH, Wellman NA, Geaney DP, Cowen PJ, Feldon J, Rawlins JN (1996). Antipsychotic drug effects in a model of schizophrenic attentional disorder: a randomized controlled trial of the effects of haloperidol on latent inhibition in healthy people. Biol Psychiatry 40: 1135-1143.
Williams JH, Wellman NA, Geaney DP, Feldon J, Cowen PJ, Rawlins JN (1997). Haloperidol enhances latent inhibition in visual tasks in healthy people. Psychopharmacology (Berl) 133: 262-268.

Wong J, Weickert CS (2009). Transcriptional interaction of an estrogen receptor splice variant and ErbB4 suggests convergence in gene susceptibility pathways in schizophrenia. J Biol Chem 284: 18824-18832.

Woolley CS, Schwartzkroin PA (1998). Hormonal effects on the brain. Epilepsia 39(Suppl 8): S2-S8.

Woolley CS, Weiland NG, McEwen BS, Schwartzkroin PA (1997). Estradiol increases the sensitivity of hippocampal CA1 pyramidal cells to NMDA receptor-mediated synaptic input: correlation with dendritic spine density. J Neurosci 17: 1848-1859.

Wozniak DF, Dikranian K, Ishimaru MJ, Nardi A, Corso TD, Tenkova $\mathrm{T}$ et al (1998). Disseminated corticolimbic neuronal degeneration induced in rat brain by MK-801: potential relevance to Alzheimer's disease. Neurobiol Dis 5: 305-322.

Yu PL, Wu CI, Lee TS, Pan WH, Wang PS, Wang SW (2009). Attenuation of estradiol on the reduction of striatal dopamine by amphetamine in ovariectomized rats. J Cell Biochem 108: 1318-1324.

Zhou W, Cunningham KA, Thomas ML (2002). Estrogen regulation of gene expression in the brain: a possible mechanism altering the response to psychostimulants in female rats. Brain Res Mol Brain Res 100: 75-83. 